\title{
Processes of Acquisition a Second Language and Learning a Foreign Language: Terminology Standardisation and Harmonization
}

\section{Процеси засвоєння і вивчення другої та іноземної мови: унормування і гармонізація основних термінів}

Oksana Turkevych Ph.D. in Linguistics, Associate Professor

\section{Оксана Туркевич}

кандидат філологічних наук, доцент

E-mail: turkevycho@gmail.com orcid.org/0000-0001-8392-6199

Ivan Franko National University of Lviv, Department of Ukrainian Applied Linguistics

$\triangle 1$, Universytetska Str., Lviv, Ukraine, 79000
Львівський начіональний університет імені Івана Франка, кафедра украӥнського прикладного мовознавства вул. Університетська, 1, м. Львів, Україна, 79000

Original manuscript received August 01, 2018

Revised manuscript accepted February 20, 2019

\section{ABSTRACT}

The article analyzes microgroup of terms relating to the process of second language acquisition or foreign language learning (language aptitude, interlanguage, language competence, language performance, language proficiency). The semantics of this group is analyzed and some aspects of normalization (compliance with linguistic and terminological norms) and harmonization (compliance with variants that function in English) are proposed.

The difference between the terms of language acquisition and language learning is specified. The author of the article proves the idea that the acquisition of 
the second language is an unconscious process of producing the language, when a person implicitly assimilates speech samples and produces them intuitively. Learning a foreign language is a conscious process of producing a language when a person explicitly learns speech samples and produces them consciously.

Language aptitude denotes the innate ability of a person which develops with the experience of communication, and it is a kind of mechanism that allows the mental and physiological levels to master the language.

It is revealed that bilingualism (natural and educational) can be the result of different strategies of language mastering and thus there are various mechanisms for its formation. It is found out that interlanguage is a language that is characterizing a person who learns a new language, and it is the result of the interaction of language systems, rules, norms of native language and the language which is learned. It is dynamic and reflects the appropriate level of language proficiency.

The relationship between terms language competence (a set of language knowledge), language performance (production and comprehension of language), and language proficiency (ability of an individual to speak or perform in a language according to the aim of communication) is determined. These terms are at the stage of entry into Ukrainian science.

Key words: second language acquisition, foreign language learning, language aptitude, interlanguage, language competence, language performance, language proficiency.

\section{Вступ}

Різноаспектні дослідження психічних процесів, що супроводжують опанування нерідної мови, тривають і розвиваються. Вони або дидактично спрямовані, або аналізують взаємодію мов в контексті двомовності й багатомовності, або намагаються простудіювати специфіку оволодіння якоюсь конкретною мовою.

Система понять, якою оперують дослідники, описуючи, як особа засвоює чи вживає мову, демонструє наукові надбання, проте система українських термінів, які номінують ці поняття $\epsilon$ суперечливою. По-перше, один термін може мати різні значення або трактування, по-друге, на позначення одного i того самого поняття використовують різні терміни. Терміносистема потребує унормування, тобто узгодження значень із формою і встановлення їх відповідності актуальним термінологічним нормам. Ще однією сучасною проблемою на україномовному грунті $\epsilon$ переклад i вживання термінів, зокрема з англомовних джерел. В цьому аспекті 
потрібна гармонізація - узгодження запозичених варіантів із тими, які вже функціонують. Тобто актуальність дослідження в тому, щоб встановити відповідність між формою і значенням основних термінів, що позначають процеси засвоєння і вивчення мови.

У закордонних працях психолінгвістичний аспект опанування нерідної мови досліджено в численних розвідках, наприклад, В. Гекоскі (Gekoski, 1980): контекст засвоєння мови і іï формування у білінгвів; Д. Хо (Но, 1987): труднощі вивчення мови, зумовлені позамовними і внутрішньомовними факторами; Г. Андреу, Ф. Влакос, Е. Андреу (Andreou, Vlachos \& Andreou, 2005): чинники, які впливають на вивчення другої мови. У прикладному психолінгвістичному аспекті Ф. Дженіс, Е. Хамаян (Genesee \& Hamayan, 1980) досліджують індивідуальні відмінності вивчення другої мови, К. Стейнхауер (Steinhauer, 2006) порушує проблему динаміки засвоєння другої мови, П. Ребушат, Дж. Вільямс (Rebuschat \& Williams, 2012) аналізують роль імпліцитних й експліцитних знань у засвоєнні другої мови.

Підгрунтям запропонованого дослідження стали праці О. Залевської (Залевская, 2009, 2016) (аспект двомовності), Р. Еліса (Ellis, 1997) і С. Крашена (Krashen, 1981) (різниця між засвоєнням і вивченням мови), О. Леонтьєва (Леонтьев, 1999) (психолінгвістичний аспект оволодіння мовою), Л. Калмикової (Калмикова, 2008) (мовленнєва діяльність).

Метою статті є проаналізувати семантичну групу термінів, які позначають процеси вивчення-засвоєння нерідної (іноземноїдругої) мови. Завданнями: 1) з'ясувати семантичний розвиток термінів, які номінують процеси опанування мови; 2) порівняти зазначені терміни з відповідниками в англійській мові; 3) встановити семантичне наповнення термінів і виділити мікропарадигми, які вони формують; 4) запропонувати правильні відповідники з погляду термінологічної норми й аспектів гармонізації.

Усі досліджувані концепти умовно втілюються у трьох етапах. Перший описує, що «чинить» особа стосовно нерідної мови (вивчає, засвоює, володіє, опановує тощо), другий - що відбувається тоді, коли особа вже почала опановувати нову мову (наприклад, проміжна мова), третій - яким є результат, що особа «породжує». 


\section{Методи та методики дослідження}

У дослідженні для вивчення процесів психічної діяльності, що супроводжує опанування нерідної мови використано обсерваційний метод. Контент-аналіз вибрано з метою з'ясування семантичного навантаження мовних одиниць на позначення процесів засвоєння чи вивчення мови (другої та іноземної).

\section{Результати та дискусії}

Кожна людина, яка починає опановувати іноземну чи другу мову, робить перші кроки, свідомі чи несвідомі, у дитячому чи дорослому віці; опановує одну чи більше мов тощо. Передусім, щоб оволодіти мовою, слід мати природні, вроджені якості, які слід розвивати. Фахівці оперують терміном мовна здатність, а також часто як синонім вживають терміносполуку мовні здібності. В англомовній літературі вживають термін language aptitude, відповідником якого, на наш, погляд, $є$ термін мовна здатність. «Мовна здатність охоплює такі спроможності: наслідувати та розрізняти звуки нової мови, розпізнавати різні граматичні функції слів у реченні, виучувати напам'ять, робити висновки на основі правил. Мовна здатність не враховує інтелігентності, мотивації, зацікавлень» (Richards \& Schmidt, 2002: 258). Таке тлумачення лінгводидактично спрямоване й демонструє конкретні вияви мовної здатності у відповідних діях. У психолінгвістичному аспекті О. Леонтьєв мовну здатність трактує як частину мовленнєвого механізму (Леонтьев, 1999), О. Залевська як «пристрій», призначений для опрацювання відповідних процесів (Залевская, 2016). М. Орап вживає термін мовленнєва здатність і обгрунтовує думку, що вона охоплює дві функції «можливості (психофізіологічна складова) та готовності (психологічна складова)». Мовленнєва здатність $є$ «психофізіологічною особливістю i одночасно «елементом внутрішньої підструктури системи мовленнєвого досвіду особистості» (Орап, 2013: 122).

Відтак дискусійним $є$ питання вибору терміна - мовна чи мовленнєва здатність. На наш погляд, зазначені одиниці позначають одне поняття і не слід розрізняти їх семантично. Доречнішим, на 
наш погляд, буде термін мовна здатність, а не мовленнєва. Оскільки мовна здатність позначає вроджену спроможність особи, яка розвивається з досвідом спілкування, і є своєрідним механізмом, який на психофізіологічному рівні уможливлює опанування мови.

Маючи мовну здатність особа може почати вивчати мову свідомо або засвоювати несвідомо. «Засвоєння мови (language acquisition) - вивчення і розвиток мови. Вивчення першої рідної мови називають засвоєнням першої мови, вивчення другої чи іноземної мови - засвоєнням другої мови. Одні науковці вживають засвоєння і вивчення як синоніми, інші - розрізняють. Термін вивчення стосується свідомого процесу, який залучає навчання експліцитних правил мови і спостереження за результатом, він здебільшого типовий в контексті навчання іноземної мови у класі. Термін засвоєння стосується несвідомого процесу інтерналізації (внутрішнього перетворення) правил, $є$ результатом від впливу (дії) до зрозумілого вживання (уведення в дію), коли увага учня спрямована на значення, а не на форму, що більш властиво для контексту другої мови. Інші вживають аквізиція (засвоєння) тільки в контексті першої мови» (Richards \& Schmidt, 2002: 284). Таке тлумачення узагальнено описує актуальну ситуацію - трактування термінів засвоєння і вивчення мови. Оскільки у полі зору нашого дослідження є процеси, що стосуються другої (іноземної) мови, то уважаємо за доцільне навести погляди Р. Еліса (Ellis, 1997) i С. Крашена (Krashen, 1981) - учених, праці яких є основоположними. Р. Еліс у розвідці «Second language acquisition» виокремлює новий напрямок - засвоєння другої мови, хоча науковець і не розрізняє термінів засвоювати і вивчати, постійно використовує слово learn, learning. На думку науковця, засвоєння другої мови (second language acquisition) - галузь, яка досліджує спосіб, в який особа вивчає мову іншу, ніж iï рідна мова. Другу мову можна вивчати у класі чи поза його межами; можна вивчати у природний спосіб, живучи у країні, де нею розмовляють, чи вивчати з викладачем за певною програмою (Ellis, 1997: 3).

С. Крашен, навпаки, демонструє чітку різницю у процесах засвоєння і вивчення. «Засвоєння мови (Language acquisition) значеннєва взаємодія (обмін значеннями) - природна комунікація у якій мовці пов'язані не формою своїх зразків висловлювання (utterances), а повідомленнями, які вони передають і розуміють. 
Виправляння помилок й експліцитне вивчення правил не стосуються засвоєння мови. Прийнятно $є$ лише те, що носії мови можуть видозмінювати свої зразки мовлення 3 метою допомогти тим, хто засвоює мову. Учні не володіють правилами вживання мови, але розмовляють і виправляють себе на основі відчуттів, інтуїції. Свідоме вивчення мови супроводжується виправлянням помилок i презентацією експліцитних правил. Корекція помилок важлива, допомагає учневі дійти до правильного представлення (вживання) мовних узагальнень» (Krashen, 1981: 1-2). Таким чином, засвоєння другої мови і вивчення другої мови - різні процеси.

Якщо розглянути на прикладі української мови як другої чи української мови як іноземної, то моніторинг досліджень за останні 27 років дає підстави стверджувати, що терміни засвоєння української мови як іноземної (чи другої) і вивчення української мови як іноземної (чи другої) уживають у 99\% як абсолютні синоніми. I хоча автори термінологічно не розрізняють досліджувані поняття, у своїх розвідках вони аналізують різні, на наш погляд, процеси вивчення i засвоєння. Що не сприяє унормуванню i розвитку подальших досліджень в цій галузі.

Беручи до уваги погляди С. Крашена (Krashen, 1981) і розвиток галузі second language acquisition у світовій науці, звертаючи особливу увагу на психолінгвістичні відмінності у процесах засвоєння і вивчення мови (детальніше див. нижче) уважаємо за потрібне розмежовувати досліджувані терміноодиниць в українській науці. Закономірно також, що коли мова йтиме про українську мову як другу (хоча на практиці й третю, четверту тощо) то більш доцільно говорити про іiї засвоєння, коли ж йдеться про українську мову як іноземну, то варто говорити про іï вивчення.

Iз розвитком багатомовності i багатокультурності як визначальних ознак суспільства у XXI столітті сформувалося також поняття багатомовного (мультилінгвального) засвоєння (Multilanguage Acquisition). Науковці пропонують різні моделі такого засвоєння, найпоширенішою 3 яких є Extended Competition Model - розширена модель змагання, яка наголошує на постійному змаганні (суперництві) між різними варіантами, що $\epsilon$ основою мовного продукування і вправляння (Kroll \& Groot, 2005). Разом із цим ця модель передбачає те, що «вивчення другої (розуміти наступної. O.T.) мови завжди мусить брати до уваги закони 
процесу формування першої мови (розуміти - попередньої чи попередніх. О.T.) завдяки впливу мовного перенесення і спільних механізмів засвоєння мови» (Kroll \& Groot, 2005: 164).

Засвоєння мов в контексті білінгвізму чи багатомовності це взаємодія таких чинників, як «мовний трансфер, типологічні відмінності й взаємодія мов, соціальні умови поширення другої мови, вік (в якому засвоюють мову), рівень розумового розвитку особи, мотивація, навчальне середовище, вплив мови (language exposure)» (Kroll \& Groot, 2005: 3). Поява нового поняття (Multilanguage Acquisition) додатково свідчить про потребу розмежовувати два поняття засвоєння і вивчення стосовно іноземних чи других мов і відповідно вживати два терміни 3 відповідними значеннями. Такий аспект унормування допоможе уніфікувати й усі інші терміни, що більш детально стосуються процесів опанування мови в різний спосіб.

У контексті пошуків правильних термінів щодо найменування «дій», які особа виконує стосовно нерідної мови, також доцільно згадати про лексеми оволодіння, опанування чи дієслівні відповідники: оволодіти (оволодівати), опановувати (опанувати).

На думку О. Леонтьєва, лексема оволодіння мовою (овладение языком) охоплює три поняття: оволодіння рідною мовою (language acquisition, mother tongue acquisition), вторинення усвідомлення рідної мови (зокрема у школі) і оволодіння іноземною мовою (learning) (Леонтьєв, 1999: 218). Тобто це родова одиниця, яка стосується усіх «дій» щодо першої чи другої (іноземної) мови.

В українській мові синонімними $є$ лексичні значення одиниць оволодівати i опановувати. Оволодівати - «набувати грунтовних знань, умінь, навичок і т. ін. в чому-небудь» (Словник української мови, 1974: 611). I опановувати - «1. Грунтовно засвоювати щось, оволодівати чим-небудь. 2. Навчатися користуватися чим-небудь» (Словник української мови, 1974: 702). Наведені дефініції уможливлюють обгрунтувати, що лексеми оволодіння, опанування $\epsilon$ гіперонімами, що охоплюють поняття засвоєння i вивчення. Традиційно їх уживають у психолінгвістичних і лінгводидактичних працях, i, на наш погляд, це доцільно робити, але їх термінізація (перехід у визначену терміносистему) ще не відбувся. I тому розглядати їх в термінологічному унормуванні чи гармонізації недоцільно. 
Після того як ми з'ясували номінації понять, які відображають процеси, які особа здійснює стосовно нової нерідної мови, логічно $€$ прослідкувати власне механізм «народження» нової мови. Такі дослідження є об'єктом нейрофункціональних розвідок. Ми розглянемо основні теорії цих процесів у більш описовому аспекті, пов'язаному з багатомовністю. О. Залевська дуже детально розмежувала природний i навчальний білінгвізм. Дослідниця обгрунтувала важливість «взаємодії перцептивних, когнітивних i афективних процесів», тобто «мовні явища другої чи іноземної мови не просто засвоюють як нові вербальні «факти», а вони є пов'язані 3 визначеними перцептивними образами, когнітивними одиницями i емоційно-оцінними переживаннями». До того ж психічне життя особи протікає в постійній динаміці рівнів усвідомлення, у процесах мовно-мисленнєвої діяльності $є$ постійна опора на образ світу і пов'язані з ним різноманітні вивідні знання (мовні й енциклопедичні) (Залевская, 2009: 12)

Дослідниця вказує на те, що в засвоєнні другої мови формуванні двомовності, важливо розглянути умови, процеси й результати (продукти).

Умови можуть бути природні (справжні) чи навчальні. Відповідно й опанування мови відбувається в різний спосіб. Таблиця 1 демонструє відмінності основних процесів оволодіння мовою й укладена на основі розвідки О. Залевської (Залевская, 2009).

Таке порівняння дає нам чітку підставу ствердити, що коли в особи формується навчальний білінгвізм - він $\epsilon$ результатом вивчення мови, природний - це наслідок засвосння мови.

Проте деколи у відповідних умовах може бути важко встановити, який тип білінгвізму формується, особливо це стосується дитячого віку. Наприклад, якщо дитина, народжена в українській сім'ї емігрантів, яка першою мовою має мову країниперебування, а другою мовою - українську мову, яку вона, з одного боку, засвоює від батьків, а 3 іншого боку - вивчає у школі чи в інший спосіб. Усі процеси, наведені в таблиці, будуть змішаними. На наш погляд, висновки О. Залевської (Залевская, 2009) підходять для аналізу формування двомовності в окреслених чітких умовах, коли особа або цілеспрямовано вивчає мову або засвоює іï несвідомо під впливом мовного оточення (що значно рідше буває в дорослому віці). 
Processes of Acquisition a Second Language and Learning...

Таблиця 1. Природний і навчальний білінгвізм

\begin{tabular}{ll}
\hline \multicolumn{1}{c}{ Природний білінгвізм: ознаки } & \multicolumn{1}{c}{ Навчальний білінгвізм: ознаки } \\
\hline «Вливання» мови за допомогою спільної & Вивчання мови в умовах обмеженої \\
мовленнєвої практики. & мовленнєвої практики. \\
Можливість не застосовувати вольових & Відчутна необхідність щоденних вольових \\
зусиль. & зусиль. \\
Перевага неусвідомлених процесів & Перевага свідомо реалізованих процесів \\
аналізу, синтезу, порівняння, класифікації. & аналізу, синтезу, порівняння, класифікації. \\
Перевага автоматизованих операцій & Перевага неавтоматизованих операцій \\
вибору слів і мовленнєвих моделей. & вибору слів і мовленнєвих моделей. \\
«Перемикання» з однієї мови на іншу. & Переклад з однієї мови на іншу. \\
Паралельне (у дитинстві) формування & Формування системи другої мови за \\
картини світу і двох мовних систем у & наявності картини світу, закріпленої у \\
справжніх ситуаціях спілкування. & мовній картині світу першої мови. \\
Акцентування уваги на смислі & Акцентування уваги на мовних засобах. \\
пізнаваного, вимовленого, прослуханого. & \\
\hline
\end{tabular}

Досліджуючи процес «народження» другої чи іноземної мови, на увагу заслуговує термін проміжна мова (англійські відповідники - interlanguage, approximative system, transitional competence, learner language).

Узагальнене тлумачення проміжної мови як «мови, яка відрізняється і від рідної мови і від тої, яку вивчають; проміжну мову особа продукує завдяки запозичуванню зразків 3 рідної мови, розширюванню зразків завдяки аналогії, вираженню значень за допомогою відомих слів і граматики» (Richards \& Schmidt, 2002: 76) більшою мірою відображає лінгводидактичний підхід. Що стосується психолінгвістичного, то О. Залевська об'єктивно зазначає, що проміжна мова $\epsilon$ «динамічною функціональною системою, яка $є$ виявом багатьох внутрішніх і зовнішніх чинників у типових ситуаціях; така система формується в результаті своєрідного переробляння мовленнєвого i пізнавального досвіду в другій мові 3 опорою на вже відоме 3 рідної мови, а також у взаємодії уже наявної картини світу, сформованої на основі першої мови 3 пізнаваною специфікою другої мови і другої культури (Залевская, 2009: 14).

О. Залевська покликаючись на Л. Селінкера зазначає, що проміжна мова - це окрема мовна система, яка $є$ продуктом спроби учня цілісно осягнути мову, яку він вивчає; це проміжна 
система, складена із правил, отриманих 3 допомогою різних стратегій, зокрема спрощення (simplification), надузагальнення (overgeneralization), перенесення (transfer) (Залевская, 2016: 57). Закономірно, що проміжна мова - динамічна і хоча є типові ознаки, усе таки вона специфічна в кожного мовця. Уважаємо, що цей термін повною мірою відображає відповідне поняття. Проміжна мова - перехідний етап у вивченні нової мови, і за своєю суттю $€$ результатом взаємодії мовних систем, правил, норм рідної мови та мови, яку вивчають. Проміжна мова - особливе явище. Воно індивідуальне за специфікою в кожної особи, яка вивчає мову, i водночас притаманне усім, хто вивчає нову мову. Проміжна мова - змінна і є відображенням певного рівня володіння мовою в особи, яка іï вивчає.

Коли мова йде про опанування мови - зокрема результат цього процесу - то вживають терміни competence, second/foreign language proficiency, language performance, а у виборі їх українських відповідників існують проблеми.

До терміна competence відповідником $\epsilon$ компетенція (хоча часто неправильно вживають компетентність), до терміна second/ foreign language proficiency - вільне володіння мовою, навички володіння мовою, рівень володіння мовою, language performance вживання мови, застосування мови. Термін компетенція $є$ родовим стосовно мікрогрупи - мовна компетенція, мовленнєва компетенція, комунікативна компетенція і позначає сукупність теоретичних знань, практичних умінь і навичок, які є метою вивчення мови.

Застосування мови, вживання мови - процес використання системи мови з метою спілкування у визначених умовах. Переклад терміна second/foreign language proficiency $є$ дискусійним питанням, a його значення грунтовно пояснюють Загальноєвропейські рекомендації 3 мовної освіти, які «відходять від панівної у прикладній лінгвістиці теорії, за якою розрізняють компетенцію (приховані знання за Н. Хомським, competence ) і застосування мови (виражену діяльність, performance)» і пропонують «вживати новий термін proficiency як виражену частину компетенції (competence), отриману під час дії - застосування мови (performance). Proficiency це термін, який охоплює здатність виконувати мовленнєву діяльність (communicative language activities) одночасно залучаючи загальну i комунікативну мовну компетенцію (лінгвістичну, соціолінгвістичну, 
прагматичну) i застосовувати властиві комунікативні стратегії» (Common European Framework of reference for languages, 2017: 32). Варіанти перекладу терміна proficiency - вміння володіння мовою, майстерність володіння мовою, навички володіння мовою, рівень володіння мовою. На наш погляд, його українським відповідником може стати терміносполука вправність володіння мовою.

Говорячи про оволодіння другою чи іноземною мовою, не можна оминути увагою термін мовленнєва діяльність. Оскільки він охоплює дуже багатогранне поняття, то навіть сформувалася ціла теорія мовленнєвої діяльності, предметом якої, на думку Л. Калмикової, є мовленнєві операції й дії (Калмикова, 2008: 66-68).

Порівняльна таблиця 2 дає змогу чітко побачити різне розуміння мовленнєвої діяльності й англійські відповідники, а також іiї своєрідну структуру.

Таблиця 2. Трактування мовленнєвої діяльності

\begin{tabular}{|c|c|c|c|}
\hline Джерела & $\begin{array}{c}\text { Психолінгвістичний } \\
\text { контекст }\end{array}$ & $\begin{array}{c}\text { Лінгводидактичний } \\
\text { контекст }\end{array}$ & $\begin{array}{l}\text { Діяльнісний підхід } \\
\text { (Соmmon European } \\
\text { Framework of Reference } \\
\text { for Languages: learning, } \\
\text { teaching, assessment) }\end{array}$ \\
\hline $\begin{array}{l}\text { Англійські } \\
\text { відповідники }\end{array}$ & $\begin{array}{l}\text { Speech acts } \\
\text { speech activity }\end{array}$ & $\begin{array}{l}\text { Four language skills } \\
\text { (listening, speaking, } \\
\text { reading, writing) }\end{array}$ & $\begin{array}{l}\text { Four modes of } \\
\text { communication: reception, } \\
\text { production, interaction, } \\
\text { mediation }\end{array}$ \\
\hline $\begin{array}{l}\text { Українські } \\
\text { відповідники }\end{array}$ & $\begin{array}{l}\text { Мовленнєва } \\
\text { діяльність }\end{array}$ & $\begin{array}{l}\text { Чотири види } \\
\text { мовленнєвої } \\
\text { діяльності (слухання, } \\
\text { говоріння, читання, } \\
\text { писання) }\end{array}$ & $\begin{array}{l}\text { Чотири способи } \\
\text { спілкування: сприйняття } \\
\text { (рецепція), продукування, } \\
\text { взаємодія, медіація } \\
\text { (посередницька діяльність) }\end{array}$ \\
\hline Структура & $\begin{array}{l}\text { Мовленнєві операції } \\
\text { і дії }\end{array}$ & $\begin{array}{l}\text { Мовленнєві навички } \\
\text { і вміння }\end{array}$ & $\begin{array}{l}\text { Комунікативні (мовленнєві) } \\
\text { компетенції і стратегії }\end{array}$ \\
\hline
\end{tabular}

У таблиці чітко простежено трансформацію розуміння мовленнєвої діяльності як механізму, що складається з мовленнєвих операцій і дій, у своєрідне практичне втілення в реальному житті, яке віддзеркалює погляд, що коли особа вивчає нову іноземну мову, то вона «творить» мовленнєву діяльність. Перспективою дослідження є більш детальний опис мовленнєвої діяльності на міжгалузевому рівні. 


\section{Висновки}

Таким чином, можна узагальнити, що з людським розвитком відбувається щоразу нове розуміння того як особа опановує нову (наступну) мову. Терміни хоча i мають на меті точно і влучно номінувати усі процеси, явища, результати оволодіння іноземною чи другою мовою перебувають на стадії становлення в українській науці. Переплетення психолінгвістичних i лінгводидактичних теорій помітно впливає на виформування значення термінів. Нові концепти, описані в англомовній літературі, потребують виваженого, одностайного й системного уведення в українську наукову мову. Перспективою досліджень $є$ комплексний різноаспектний аналіз інших понять як результату досліджень закордонних вчених, зіставлення його 3 уже наявними поняттями i ïx термінними позначеннями в українській мові і створення конкретних висновків і рекомендацій і щодо форми, і щодо змісту.

\section{Література}

Залевская А.А. Введение в теорию учебного двуязычия. Тверь : Твер. гос. ун-т, 2016. 269 c.

Залевская А.А. Вопросы психолингвистической теории двуязычия. Bonpocbl психолингвистики. 2009. Вып. 10. С. 10-18.

Калмикова Л.О. Психологічні засади розрізнення операцій і дій як одиниць мовленнєвої діяльності. Гуманітарний вісник ДВНЗ «Переяслав-Хмельницький державний педагогічний університет імені Григорія Сковороди»: науковотеоретичний збірник. 2008. Вип. 15. С. 86-88.

Леонтьев А.А. Основы психолингвистики. Москва : Смысл, 1999. 288 с.

Орап М. Мовленнєва здатність та мовленнєва компетенція як елементи внутрішньої підструктури мовленнєвого досвіду особистості.

Психолінгвістика. Психолингвистика. Psycholinguistics. 2013. Вип. 14. C. $117-128$.

Словник української мови : в 11 т. Київ : Наукова думка, 1974. Т. 5.840 с.

Andreou, G., Vlachos, F., \& Andreou, E. (2005). Affecting Factors in Second Language Learning. Journal of Psycholinguistic Research, 34(5), 429-438. https://doi.org/10.1007/s10936-005-6202-0

Common European Framework of reference for languages: learning, teaching, assessment. Companion volume with new descriptors. Provisional Edition (2017). URL: https://rm.coe.int/cefr-companion-volume-with-newdescriptors-2018/1680787989

Ellis, R. (1997). Second Language Acquisition. Oxford : Oxford University Press. 
Gekoski, W.L. (1980). Language acquisition context and language organization in bilinguals. Journal of Psycholinguistic Research, 9(5), 429-449. https://doi. org/10.1007/BF01067324

Genesee, F., \& Hamayan, E. (1980). Individual differences in second language learning. Applied Psycholinguistics, 1(1), 95-110. https://doi.org/10.1017/ S0142716400000758

Ho, D.Y.F. (1987). Intralingual and interlingual factors in language-learning difficulty. Journal of Psycholinguistic Research, 16(5), 399-416. https://doi.org/10.1007/ BF01073270

Krashen, S.D. (1981). Second language acquisition and second language learning. Oxford : Pergamon Press.

Kroll, J.F., \& Groot, A.M.B. (2005). Handbook of Bilingualism. Psycholinguistic Approaches. Oxford: Oxford University Press.

Rebuschat, P., \& Williams, J.N. (2012). Implicit and explicit knowledge in second language acquisition. Applied Psycholinguistics, 33(4), 829-856. https://doi. org/10.1017/S0142716411000580

Richards, J.C., \& Schmidt, R. (2002). Longman Dictionary of Language Teaching and Applied Linguistics. England : Pearson.

Steinhauer, K. (2006). How dynamic is second language acquisition? Applied Psycholinguistics, 27(1), 92-95. https://doi.org/10.1017/S0142716406060176

\section{References}

Zalevskaya, A.A. (2016). Vvedenie v teoriju uchebnogo dvuyazychiya [Introduction to the theory of educational bilingualism]. Tver : Tver. gos. un-t. [in Russian].

Zalevskaya, A.A. (2009). Voprosy psyholingvisticheskoy teorii dvujazychiya [Questions of the psycholinguistic theory of bilingualism]. Voprosy psyholingvistiki Questions of psycholinguistics, 10, 10-18 [in Russian].

Kalmykova, L.O. (2008). Psykholohichni zasady rozriznennia operatsii i dii yak odynyts movlennievoi diialnosti [Psychological principles of distinguishing operations and actions as units of speech activity]. Humanitarnyi visnyk DVNZ «Pereiaslav-Khmelnytskyi derzhavnyi pedahohichnyi universytet imeni Hryhoriia Skovorody»: naukovo-teoretychnyi zbirnyk - Humanitarian Bulletin of the Pereiaslav-Khmelnytskyi Hryhorii Skovoroda State Pedagogical University: scientific and theoretical collection, 15, 86-88 [in Ukrainian].

Leontev, AA. (1999). Osnovy psyholingvistyky [Fundamentals of psycholinguistics]. Moscow : Smysl [in Russian].

Orap, M. (2013). Movlennieva zdatnist ta movlennieva kompetentsiia yak elementy vnutrishnoi pidstruktury movlennievoho dosvidu osobystosti [Speech ability and the speech competence as elements of the internal substructure of the personality's speech experience]. Psykholinhvistyka - Psycholinguistics, 14, 117128 [in Ukrainian].

Slovnyk ukrainskoi movy [Dictionary of the Ukrainian Language]. (1974). (Vols. 1-11). Kyiv : Naukova dumka [in Ukrainian].

Andreou, G., Vlachos, F., \& Andreou, E. (2005). Affecting Factors in Second Language Learning. Journal of Psycholinguistic Research, 34(5), 429-438. https://doi.org/10.1007/s10936-005-6202-0 
Прочеси засвоєння $і$ вивчення другої та іноземної мови...

Common European Framework of reference for languages: learning, teaching, assessment. Companion volume with new descriptors. Provisional Edition (2017). URL: https://rm.coe.int/cefr-companion-volume-with-newdescriptors-2018/1680787989

Ellis, R. (1997). Second Language Acquisition. Oxford : Oxford University Press.

Gekoski, W.L. (1980). Language acquisition context and language organization in bilinguals. Journal of Psycholinguistic Research, 9(5), 429-449. https://doi. org/10.1007/BF01067324

Genesee, F., \& Hamayan, E. (1980). Individual differences in second language learning. Applied Psycholinguistics, 1(1), 95-110. https://doi.org/10.1017/ S0142716400000758

Ho, D.Y.F. (1987). Intralingual and interlingual factors in language-learning difficulty. Journal of Psycholinguistic Research, 16(5), 399-416. https://doi.org/10.1007/ BF01073270

Krashen, S.D. (1981). Second language acquisition and second language learning. Oxford : Pergamon Press.

Kroll, J.F., \& Groot, A.M.B. (2005). Handbook of Bilingualism. Psycholinguistic Approaches. Oxford: Oxford University Press.

Rebuschat, P., \& Williams, J.N. (2012). Implicit and explicit knowledge in second language acquisition. Applied Psycholinguistics, 33(4), 829-856. https://doi. org/10.1017/S0142716411000580

Richards, J.C., \& Schmidt, R. (2002). Longman Dictionary of Language Teaching and Applied Linguistics. England : Pearson.

Steinhauer, K. (2006). How dynamic is second language acquisition? Applied Psycholinguistics, 27(1), 92-95. https://doi.org/10.1017/S0142716406060176

\section{АНОТАЦІЯ}

У статті проаналізовано мікрогрупу термінів, які стосуються процесу опанування другої чи іноземної мови (засвоєння другої мови, вивчення іноземної мови, мовна здатність, проміжна мова, мовна компетенція, володіння мовою, мовна вправність). Прослідковано їх семантику, запропоновано окремі аспекти унормування (відповідності мовним і термінологічним нормам) і гармонізації (відповідності варіантам, які функціонують в англійській мові).

З'ясовано, яка різниця існує між термінами засвоєння і вивчення нерідної мови. Обгрунтовано думку, що засвоєння другої мови - несвідомий процес оволодіння мовою, коли особа імпліцитно засвоює мовленнєві зразки і продукує їх інтуїтивно. Вивчення іноземної мови - свідомий прочес опанування мови, коли особа експліцитно засвоює мовленнєві зразки і продукує їх усвідомлено.

Мовна здатність позначає вроджену спроможність особи, яка розвивається з досвідом спілкування, $і \in$ своєрідним механізмом, який на психічному й фізіологічному рівнях дає змогу опанувати мовою.

Встановлено, що білінгвізм (природний і навчальний) може бути результатом різних стратегій опанування мови і відповідно існують різні механізми його формування. 3'ясовано, що проміжна мова - мова, яка властива особі, яка вивчає чи засвоює нову мову, вона є результатом взаємодії мовних 
систем, правил, норм рідної мови та мови, яку вивчають. Вона є динамічною $і$ відображає відповідний рівень володіння мовою, яку вивчають.

Визначено співвідношення між термінами: мовна компетенція (language competence) - сукупність мовних знань, застосування мови (language performance) - процес виявляння мовних знань, вправність володіння мовою (language proficiency) - вміння і навички доцільно реалізовувати мовні знання відповідно до мети спілкування. Зазначені терміни перебувають на етапі входження в українську науку.

Ключові слова: засвоєння другої мови, вивчення іноземної мови, мовна здатність, проміжна мова, мовна компетенція, володіння мовою, мовна вправність.

Туркевич Оксана. Процессы усвоения и изучения второго и иностранного языка: нормирование и гармонизация основных терминов

\section{АННОТАЦИЯ}

В статье был проведен анализ микрогруппы терминов, относящихся $к$ процессу освоения второго или иностранного языка (усвоение второго языка, изучение иностранного языка, языковая способность, промежуточный язык, языковая компетенция, владение языком, языковая подготовка).

Автор проследил их семантику и предложил отдельные аспекты нормирования (соответствия языковым и терминологическим нормам) и гармонизации (соответствия вариантам, которые функционируют в английском языке).

Автор выявил разницу, существующую между терминами освоения и изучения неродного языка. Также обосновывается мнение, что усвоение второго языка - бессознательный процесс овладения языком, когда имплицитно усвачваются и интуитивно воспроизводятся речевые образцы. Изучение иностранного языка - сознательный процесс освоения языка, когда эксплицитно усваиваются и осознанно воспроизводятся речевые образцы.

Языковая способность означает врожденную способность, развивающуюся с опытом общения и являющуюся своеобразным механизмом, который на психическом и физиологическом уровнях позволяет овладеть языком.

Было установлено, что билингвизм (природный и учебный) может быть результатом различных стратегий овладения языком, и, соответственно, существуют различные механизмы его формирования. Автор приходит к выводу, что промежуточный язык - язык, присущий человеку, который изучает или усваивает новый язык, является результатом взаимодействия языковых систем, правил, норм родного языка и изучаемого языка. Он динамичен и отражает соответствующий уровень владения изучаемого языка.

В статье определяется соотношение между терминами «языковая компетенция» (language competence) - совокупность языковых знаний, 
Процеси засвоєння $і$ вивчення другої та іноземної мови...

"владение языком» (language performance) - выявление языковых знаний и «языковая подготовка" (language proficiency) - умения и навыки целесообразно реализовывать языковые знания соответственно условиям общения. Указанные термины находятся на этапе вхождения в украинскую науку.

Ключевые слова: усвоение второго языка, изучение иностранного языка, языковая способность, промежуточный язык, языковая компетенция, владение языком, языковая подготовка. 